\title{
The Correlation between Lymphocyte Platelet Ratio and Gensini Score in Coronary Heart Disease Patients
}

\author{
Hubungan antara Rasio Platelet Limfosit dan Skor Gensini pada Pasien dengan Penyakit Jantung \\ Koroner \\ Muliana $^{1}$, Basuki Rahmat ${ }^{1^{*}}$, Seto Priyambodo ${ }^{2}$ \\ 1 Faculty of Medicine, Universitas Mataram, Jalan Majapahit No 62 Mataram, West Nusa Tenggara, Indonesia. \\ 2 Department of Biomedic, Faculty of Medicine, Universitas Mataram, Jalan Majapahit No 62 Mataram, West Nusa \\ Tenggara, Indonesia.
}

DATA OF ARTICLE:

Received: 24 Jun 2019

Reviewed: 25 Jul 2019

Revised: 23 Aug 2019

Accepted: 25 Nov 2019

\section{*CORRESPONDENCE:}

rahmatmataram98@gmail.com

DOI:

10.18196/mm.200136

TYPE OF ARTICLE:

Research

\begin{abstract}
The lymphocyte platelet ratio (LPR) is an inflammatory marker that can be used to identify the severity of coronary heart disease (CHD). This study aims to determine the correlation between the lymphocyte platelet ratio and Gensini scores in CHD patients. This research used correlative analytical research with a cross-sectional design. The sample was selected by consecutive sampling technique and obtained 51 respondents. The calculation of the LPR was carried out by dividing the number of platelets and lymphocytes in the volume unit of $10^{3} / \mathrm{mm}^{3}$. Meanwhile, the Gensini score assessment was carried out by multiplying the percentage of blockages and location of blockages based on the result of coronary angiography. Based on the Gensini score, the sample in this study was classified as mild atherosclerosis with the Gensini score <25 points, and severe atherosclerosis with the Gensini score $\geq 25$ points. The data were analyzed using the Pearson correlation test. The result showed that the average LPR value in samples with severe atherosclerosis was 124.6 and 115.3 in mild atherosclerosis. Based on the result of statistical analysis using the Pearson test, the p-value was 0.107 . It can be concluded that there is no significant correlation between the lymphocyte platelet ratio and Gensini scores in CHD patients.
\end{abstract}

Keywords: Coronary heart disease; Gensini score; Lymphocyte platelet ratio

Abstrak: Rasio platelet limfosit (LPR) adalah penanda inflamasi yang dapat digunakan untuk mengidentifikasi tingkat keparahan penyakit jantung koroner (PJK). Penelitian ini bertujuan untuk mengetahui korelasi antara rasio platelet limfosit dan skor Gensini pada pasien PJK. Penelitian ini menggunakan penelitian analitik korelatif dengan desain cross-sectional. Sampel dipilih dengan teknik consecutive sampling dan diperoleh 51 responden. Perhitungan LPR dilakukan dengan membagi jumlah trombosit dan limfosit dalam satuan volume $10^{3} / \mathrm{mm}^{3}$. Sementara itu, penilaian skor Gensini dilakukan dengan mengalikan persentase penyumbatan dan lokasi penyumbatan berdasarkan hasil angiografi koroner. Berdasarkan skor Gensini, sampel dalam penelitian ini diklasifikasikan sebagai aterosklerosis ringan dengan skor Gensini $<25$ poin, dan aterosklerosis berat dengan skor Gensini $\geq 25$ poin. Data dianalisis menggunakan uji korelasi Pearson. Hasil penelitian menunjukkan bahwa nilai LPR rata-rata dalam sampel dengan aterosklerosis berat adalah 124,6 dan 115,3 pada aterosklerosis ringan. Berdasarkan hasil analisis statistik menggunakan uji Pearson, didapatkan p-value 0,107. Dapat disimpulkan bahwa tidak ada korelasi yang signifikan antara rasio platelet limfosit dan skor Gensini pada pasien PJK. 


\section{INTRODUCTION}

Coronary heart disease (CHD) is a cardiovascular disease with high morbidity and mortality all over the world. World Health Organization (WHO) estimates in 2008, out of 17.3 million people who died of cardiovascular disease, 7.3 million of them were estimated to die of coronary heart disease, and 6.2 million died of a stroke. $^{1} \quad$ Meanwhile, the estimated prevalence of CHD in Indonesia in 2013 was $0.5 \%$ or around 883,447 people based on the medical diagnosis and $1.5 \%$ or around 2,650,340 people based on symptoms. $^{2}$

The general pathological process that causes CHD is atherosclerosis. Atherosclerosis is a chronic inflammatory response in the artery wall initiated by damage to the endothelium. ${ }^{3}$ This chronic inflammatory response to the atherosclerosis process is associated with platelet and lymphocyte production. An increase in platelet can trigger the development of atherosclerosis and plaque destabilization. Platelets will secrete chemokines, cytokines, and other inflammatory mediators such as interleukin-1 (IL-1), IL-3, and IL-6 associated with inflammation of blood vessels. Besides, lymphocytopenia is also found in chronic inflammation due to an increase in lymphocyte apoptosis which is independently associated with an increase in morbidity and mortality in CHD. 4

This lymphocyte platelet ratio (LPR) is a prognostic sign that combines two parameters that predict risk into one. In the previous studies, it was found that LPR is a common risk factor and biomarker commonly used in predicting severe atherosclerosis and is positively correlated with Gensini scores. ${ }^{5} \mathrm{~A}$ study conducted by Akboga et al. revealed that LPR is significantly and independently associated with the severity of coronary atherosclerosis in patients with stable CHD. ${ }^{6}$ Also, LPR is a predictor of cardiovascular mortality in patients with ST-segment Elevation Myocardial Infarction (STEMI) with an increase in mortality in the group with higher LPR. ${ }^{7}$

The researchers are interested in identifying the correlation between the lymphocytes platelet ratio and Gensini scores in CHD patients in Mataram City Hospital since the lymphocytes platelet ratio is a blood calculation routinely performed without additional costs and is an available marker that can help identify the severity of CHD. Based on the result of this study, it can be taken into consideration to use an easy and inexpensive LPR examination as an independent predictor of severity in CHD patients.

\section{MATERIALS AND METHOD}

This research is a correlative analytic study that aims to determine the correlation between the lymphocytes platelet ratio and Gensini scores in patients with CHD in Mataram City Hospital using a cross-sectional design conducted from May to December 2017. The subjects were patients who had been diagnosed with CHD based on clinical symptoms, physical examination, and additional examinations, such as an electrocardiogram (ECG), echocardiography, treadmill, and coronary angiography in Mataram City Hospital. Samples were selected using non-probability sampling techniques, namely consecutive sampling, and the number of samples used in this study was 51 respondents.

Inclusion criteria were patients who have been diagnosed with CHD based on ECG, echocardiography, treadmill, and coronary angiography, and patients who approved and signed a statement of willingness as a research sample. Meanwhile, the exclusion criteria included: (1) undergoing acute coronary syndrome (ACS), (2) undergoing an infectious disease, (3) currently taking anti-inflammatory medication, and (4) having a history of malignant disease. The selection was conducted by interviewing patients and identifying their medical records.

Data collection and instruments used were guided interviews using a questionnaire, a complete recording of blood test results identified from the patients' medical records, and a recording of the result of coronary angiography identified from the patients' medical records. Calculation of the ratio of lymphocyte platelets was carried out by dividing the number of platelets and lymphocytes in the volume unit of $10^{3} / \mathrm{mm}^{3}$, and the Gensini score assessment was carried out by multiplying the percentage of blockage and location of blockage based on the result of coronary angiography. Based on the Gensini score, the sample in this study was classified as mild atherosclerosis with the Gensini score $<25$ points and severe atherosclerosis with the Gensini score $\geq 25$ points. The data analysis technique used was the Pearson correlation test (parametric test), while the normal data distribution and the alternative test used were the Spearman correlation test (non-parametric test).

This study has been granted approval from the Ethics Committee of the Faculty of Medicine at the University of Mataram under number 172 / UN18.8 / ETIK / 2017. 


\section{RESULT}

Table 1. Characteristics of Research Subjects

\begin{tabular}{|c|c|c|}
\hline Patient Characteristics & $\mathrm{n}$ & $\%$ \\
\hline \multicolumn{3}{|l|}{ Age } \\
\hline$\leq 57$ years old & 28 & 54.9 \\
\hline$>57$ years old & 23 & 45.1 \\
\hline \multicolumn{3}{|l|}{ Gender } \\
\hline Male & 36 & 70.6 \\
\hline Female & 15 & 29.4 \\
\hline \multicolumn{3}{|l|}{ BMI } \\
\hline Underweight & 2 & 3.9 \\
\hline Normal & 29 & 56.9 \\
\hline Overweight & 6 & 11.8 \\
\hline Obesity & 14 & 27.5 \\
\hline \multicolumn{3}{|l|}{ Total of Platelet } \\
\hline Below normal & 2 & 3.9 \\
\hline Normal & 48 & 94.1 \\
\hline Above normal & 1 & 2 \\
\hline \multicolumn{3}{|l|}{ Total of Lymphocyte } \\
\hline Below normal & 0 & 0 \\
\hline Normal & 49 & 96.1 \\
\hline Above normal & 2 & 3.9 \\
\hline \multicolumn{3}{|l|}{ Total of Leukocyte } \\
\hline Below normal & 0 & 0 \\
\hline Normal & 45 & 88.2 \\
\hline Above normal & 6 & 11.8 \\
\hline \multicolumn{3}{|c|}{ Lymphocyte Platelet Ratio } \\
\hline$<101$ & 18 & 35.3 \\
\hline $101-171$ & 24 & 47.1 \\
\hline$>171$ & 9 & 17.6 \\
\hline \multicolumn{3}{|l|}{ Diagnosis } \\
\hline Non-significant CHD & 11 & 21.6 \\
\hline CHD $1 \mathrm{VD}$ & 7 & 13.7 \\
\hline CHD 2 VD & 15 & 29.4 \\
\hline CHD 3 VD & 18 & 35.3 \\
\hline \multicolumn{3}{|l|}{ Gensini score } \\
\hline Mild atherosclerosis & 25 & 49 \\
\hline Severe atherosclerosis & 26 & 51 \\
\hline \multicolumn{3}{|l|}{ Diabetes Mellitus } \\
\hline Yes & 19 & 37.3 \\
\hline No & 32 & 62.7 \\
\hline \multicolumn{3}{|l|}{ Hypertension } \\
\hline Yes & 29 & 56.9 \\
\hline No & 22 & 43.1 \\
\hline \multicolumn{3}{|l|}{ Smoking History } \\
\hline Non-smoker & 30 & 58.8 \\
\hline Smoker & 21 & 41.2 \\
\hline
\end{tabular}

The number of subjects who met the inclusion criteria was 51 people. The characteristics of the subjects consisted of age, gender, body mass index (BMI), interpretation of lymphocyte platelet ratio (LPR), diagnosis of $C H D$, interpretation of Gensini scores, comorbid diseases (diabetes mellitus and hypertension) and smoking history.

Based on Table 1, it showed that the total number of the study sample, which was $\leq 57$ years old, was 28 respondents (54.9\%), and $>57$ years old was 23 respondents (45.1\%). Gender distribution in this study was higher in males than females, with a total of 36 males (70.6\%) and 15 females (29.4\%). Based on the BMI sample, it can be seen that there are two underweight respondents (3.9\%), 29 respondents (56.9\%) with normal BMI, six overweight respondents (11.8\%), and 14 obese respondents (27.5\%). Furthermore, based on the result of a complete blood examination, it revealed that samples who had a total platelet below normal category were two respondents (3.9\%), those who had normal platelet were 48 respondents (94.1\%), and those who had a total platelet above normal category were one respondent (2\%). In terms of lymphocytes examination, it was found that 49 respondents (96.1\%) had normal lymphocytes, and two respondents (3.9\%) had lymphocytes above the normal category. Based on the number of leukocytes, it revealed that 45 respondents (88.2\%) had the number of leukocytes within the normal category, and six respondents (11.8\%) had the number of leukocytes above the normal category. Moreover, the calculation of the lymphocyte platelet ratio found that 18 people (35.3\%) had LPR $<101,24$ people (47.1\%) had LPR 101-171, and 9 people (17.6\%) had LPR $>171$.

Based on the diagnosis of the study sample, 11 people (21.6\%) were diagnosed with nonsignificant CHD, seven respondents (13.7\%) were diagnosed with CHD 1 VD, 15 respondents (29.4\%) were diagnosed with CAD 2 VD, and 18 respondents (35.3\%) were diagnosed with CAD 3 VD. The Gensini score showed that samples with mild atherosclerosis were 25 respondents (49\%) while 26 respondents (51\%) had severe atherosclerosis. Based on the sample of comorbid disease, 19 respondents (37.3\%) had diabetes mellitus, and 32 respondents (62.7\%) did not. Furthermore, it was found that 29 respondents (56.9\%) had hypertension, and 22 people (43.1\%) did not. The samples in this study mostly did not smoke, with a total of 30 non-smokers (58.8\%) and 21 smokers (41.2\%).

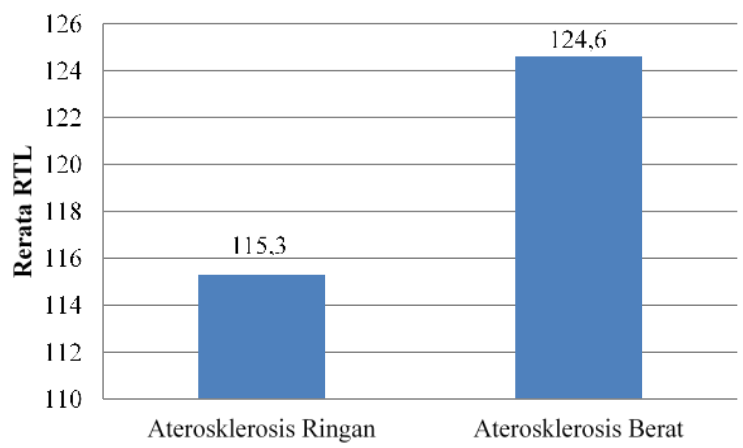

Figure 1. Average LPR in mild and severe atherosclerosis 
Based on Figure 1, it was found that the average LPR value in samples with mild atherosclerosis (Gensini score of $<25$ points) was 115.3. Meanwhile, the average LPR value in samples with severe atherosclerosis (Gensini score of $\geq 25$ points) was 124.6. It indicated that the mean of LPR in samples with severe atherosclerosis is higher than the average value of samples with mild atherosclerosis. Furthermore, based on the Pearson test result, it revealed the value of $p=0.107(p>$ 0.05), indicating that there was no significant correlation between the lymphocyte platelet ratio and Gensini scores in CHD patients in Mataram City Hospital.

\section{DISCUSSION}

Based on the result of the study, it was found that most of the study subjects were males who were $\leq 57$ years old. The average BMI of the subjects was classified as normal with the higher diagnosis of CHD 3 VD, which was mostly accompanied by hypertension and no smoking history. The calculation of the lymphocyte platelet ratio showed that 18 respondents (35.3\%) had LPR <101, 24 respondents $(47.1 \%)$ had LPR 101-171, and 9 respondents (17.6\%) had LPR >171. Furthermore, based on the Gensini score, it was found that samples with mild atherosclerosis were 25 respondents (49\%), and 26 respondents (51\%) had severe atherosclerosis.

Assessment of the severity of CHD by using Gensini scores is widely used in previous studies. The Gensini score is a rating system for the severity of coronary heart stenosis. It is carried out by multiplying the constriction percentage score and the location of the lesion in the coronary arteries. ${ }^{5}$ In this study, it was found that the diagnosis variable was significantly correlated with the severity of CHD assessed by the Gensini score with the result of the value $p=0.001$. It indicates that samples with a diagnosis of CAD 3 VD have a higher severity compared to the ones with a diagnosis of non-significant CAD, CAD 1 VD, and CAD 2 VD.

One simple marker that can be used in identifying the severity of CHD is the lymphocyte platelet ratio (LPR) obtained from complete blood tests routinely performed at a low cost. ${ }^{8}$ An increase in platelet activation plays a vital role in the initiation and the development of atherosclerosis. The total platelet is associated with both short and long-term mortality in patients with STEMI, NSTEMI, and unstable angina pectoris. ${ }^{7}$ Furthermore, lymphocyte deficiency can also increase the development of atherosclerosis. Lymphocytopenia is detected in inflammation and is associated with cardiovascular incidents. ${ }^{4}$

In a meta-analysis study conducted by Li et al. regarding the prognostic value of lymphocyte platelet ratio in acute coronary syndromes (ACS), it showed that a high LPR value is an independent factor associated with all mortality causes and cardiovascular incidents in patients with ACS. ${ }^{8}$ Furthermore, in the previous studies, it revealed that LPR is significantly and independently associated with the severity of coronary atherosclerosis in patients with stable CHD. ${ }^{6}$

In another research conducted by Sari et al. (2015), ${ }^{9}$ it was found that CHD patients had a significantly higher lymphocyte neutrophil ratio and lymphocyte platelet ratio compared to patients with normal coronary angiography results. This LPR is a simple method that can predict the severity of CHD and can be part of a cardiovascular evaluation before coronary angiography. ${ }^{9}$ LPR is a predictor of cardiovascular mortality in patients with STsegment Elevation Myocardial Infarction (STEMI) with an increase in mortality in the group with higher LPR.7 Besides that, LPR is associated with the severity of CHD. It has a positive correlation indicating that the higher the LPR value is, the higher the severity of CHD will be. 4

In this study, it was found that there was no significant correlation between the ratio of lymphocyte platelets and the Gensini score in patients with CHD in Mataram City Hospital with a value of $p>0.05$. In contrast, the previous studies showed a significant relationship between the ratio of lymphocyte platelets and the severity of CHD patients assessed by the Gensini score. The contrast can be caused by the absence of a control group in this study. Aging causes an increase in the prevalence of ACS and the deterioration of the prognosis. Moreover, it was also found that patients who had high LPR were dominated by the elderly. ${ }^{7}$ In contrast, the samples of this study were mostly $<70$ years old that can influence the result of the study.

This study revealed that a total platelet and lymphocyte identified in the samples were categorized as normal. It affected the result of this study shows that only nine respondents had LPR value $>171$ and that the result of this study was insignificant. Meanwhile, the previous studies assert that an increase in the number of platelets could trigger an increase in the number of coronary stenoses, which certainly affects the severity of CHD. Moreover, a decrease in lymphocytes is also independently associated with an increase in morbidity and mortality in CHD. ${ }^{4}$ 
Another factor that can influence the result of this study is the history of the treatment of the study samples. Most of the samples in this study had received standard CHD therapy, namely statins, aspirin, and clopidogrel. Aspirin, an antiplatelet agent, frequently given along with clopidogrel, is a medicine used to inhibit an ADP receptor. Statin, which is an inhibitor to hydroxymethyl glutariccoenzyme, is also frequently given. ${ }^{10}$ These drugs can influence the result of this study, such as clopidogrel, which has a platelet inhibitory effect that can affect the value of the lymphocyte platelet ratio. The effects of these drugs are influenced by the dose given and the severity of endothelial dysfunction and platelet reactivation. ${ }^{11}$

LPR values are also influenced by comorbid diseases experienced by the study samples, such as hypertension and diabetes mellitus. LPR as a marker of inflammation significantly increased in the nondipper hypertension group, which consisted of individuals with a normal systolic and diastolic blood. ${ }^{12}$ In addition, it was also found that LPR significantly decreased in prediabetes and early stages of diabetes. However, it will be likely to increase in the later stages of the disease. ${ }^{13}$ This study did not consider the severity when the study sample underwent the comorbid disease. This factor is also what has influenced the result of this study.

Thus, several factors that led to the study showing insignificant correlation between the lymphocyte platelet ratio and Gensini scores in CHD patients in Mataram City Hospital are such as there was no control group, the majority of the sample was $<70$ years old, and the majority of the total platelet and lymphocyte in this study sample is categorized as normal. Furthermore, there are several confounding factors, such as the history of the treatment and comorbidities experienced by the samples.

In terms of the limitations, this study used a cross-sectional method and was only conducted to CHD patients in City Hospital (single centerbased study) so that the sample used can only describe the CHD population in the city of Mataram. It only focused on the influence of one inflammatory marker that affects the severity of CHD, without considering other inflammatory markers such as C-reactive protein and so on. Moreover, this study has not been able to establish a diagnosis of severity history, which is an exclusion criterion in this study by using a standard gold examination. In addition, this study cannot control the confounding factors that can influence the result of this study.

\section{CONCLUSION}

There is no significant correlation between the ratio of lymphocyte platelets and Gensini scores in CHD patients in Mataram City Hospital.

\section{REFERENCES}

1. Mendis, S., Puska, P., Norrving, B., \& World Health Organization. Global atlas on cardiovascular disease prevention and control. Geneva: World Health Organization. 2011.

2. Kemenkes, R. I. Infodatin: Situasi Kesehatan Jantung. Pusat Data dan Informasi Kementerian Kesehatan RI, 1-8. 2014.

3. Datta, S., Iqbal, Z., \& Prasad, K. R. Comparison between serum hsCRP and LDL cholesterol for search of a better predictor for ischemic heart disease. Indian Journal of Clinical Biochemistry, 2011; 26 (2): 210-213.

4. Zhou, D., Wang, G., Fan, Y., Wan, Z., \& Liu, X. Platelet to lymphocyte ratio is associated with the severity of coronary artery disease and clinical outcomes of percutaneous coronary intervention in the Chinese Han population. Experimental and therapeutic medicine, 2017; 13 (2): 731-738.

5. Yüksel, M., Yıldız, A., Oylumlu, M., Akyüz, A., Aydın, M., Kaya, H., ... \& Alan, S. The association between platelet/lymphocyte ratio and coronary artery disease severity. Anatolian journal of cardiology, 2016; 15 (8): 640.

6. Akboga, M. K., Canpolat, U., Yayla, C., Ozcan, F., Ozeke, O., Topaloglu, S., \& Aras, D. Association of platelet to lymphocyte ratio with inflammation and severity of coronary atherosclerosis in patients with stable coronary artery disease. Angiology, 2016; 67 (1): 89-95.

7. Temiz, A., Gazi, E., Güngör, Ö., Barutçu, A., Altun, B., Bekler, A., ... \& Gazi, S. Platelet/lymphocyte ratio and risk of in-hospital mortality in patients with ST-elevated myocardial infarction. Medical science monitor: international medical journal of experimental and clinical research, 2014; 20: 660 .

8. Li, H., Zhou, Y., Ma, Y., Han, S., \& Zhou, L. The prognostic value of the platelet-to-lymphocyte ratio in acute coronary syndrome: a systematic review and meta-analysis. Kardiologia Polska (Polish Heart Journal), 2017; 75 (7): 666-673.

9. Sari, I., Sunbul, M., Mammadov, C., Durmus, E., Bozbay, M., Kivrak, T., \& Gerin, F. Relation of neutrophil-to-lymphocyte and platelet-to-lymphocyte ratio with coronary artery disease severity in patients undergoing coronary angiography. Kardiologia Polska (Polish Heart Journal), 2015; 73 (12): 1310-1316. 
10. Irmalita, J. D., Andrianto, S. B., Tobing, D. P. L., Firman, D., \& Firdaus, I. Pedoman tatalaksana sindrom koroner akut. ke-3. Indonesia: PERKI. 2015.

11. Efe, E., Kocayiğit, I., Türker, P. M., Murat, K., Erkan, A., Sedat, T., ... \& Bahri, A. Platelet-tolymphocyte ratio but not neutrophil-to-lymphocyte ratio predicts high on-treatment platelet reactivity in clopidogrel-treated patients with acute coronary syndrome. Indian journal of pharmacology, 2016; 48 (4): 355.
12. Bayrakci, N., Ozkayar, N., Akyel, F., Ates, I., Akyel, S., \& Dede, F. The platelet-to-lymphocyte ratio as an inflammation marker in non-dipper hypertensive patients. Hippokratia, 2015; 19 (2): 114.

13. Mertoglu, C., \& Gunay, M. NeutrophilLymphocyte ratio and Platelet-Lymphocyte ratio as useful predictive markers of prediabetes and diabetes mellitus. Diabetes $\mathcal{E}$ Metabolic Syndrome: Clinical Research Eु Reviews, 2017; 11: S127-S131. 